\title{
Assessment of Indian Medical Graduate (IMG)'s knowledge about emergency contraception (EC) in a medical college of Himachal Pradesh
}

Monika Jindal $^{1}$, Jai Gopal Vohra ${ }^{2}$, Jaswinder Kaur ${ }^{3}$, Santosh Minhas ${ }^{4}$, Gurmit Singh ${ }^{5}$

${ }^{1}$ Professor Obstetrics and Gynaecology, Maharishi Markandeshwar Medical College and Hospital Kumarhatti, Solan, Himachal Pradesh; ${ }^{2}$ Associate Professor, Department of Community Medicine, Maharishi Markandeshwar Medical College and Hospital Kumarhatti, Solan, Himachal Pradesh; ${ }^{3}$ Professor, Department of Physiology Maharishi Markandeshwar Medical College and Hospital Kumarhatti, Solan, Himachal Pradesh; ${ }^{4}$ Professor \& Head Obstetrics \& Gynaecology, Maharishi Markandeshwar Medical College and Hospital Kumarhatti, Solan, Himachal Pradesh; ${ }^{5}$ Professor \& Head Community Medicine, Maharishi Markandeshwar Medical College and Hospital Kumarhatti, Solan, Himachal Pradesh

\begin{tabular}{|c|c|c|c|c|c|c|c|c|}
\hline Abstract & Introduction & Methodology & $\underline{\text { Results }}$ & Conclusion & References & Citation & \multicolumn{2}{|c|}{ Tables / Figures } \\
\hline \multicolumn{9}{|c|}{ Corresponding Author } \\
\hline \multicolumn{8}{|c|}{$\begin{array}{l}\text { Dr Jai Gopal Vohra, Associate Professor, Department of Community Medicine, Maharishi Markandeshwar } \\
\text { Medical College and Hospital Kumarhatti, Solan, Himachal Pradesh } 173229 \\
\text { E Mail ID: vohra05@gmail.com }\end{array}$} & 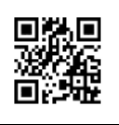 \\
\hline
\end{tabular}

\section{Citation}

Jindal M, Vohra JG, Kaur J, Minhas S, Singh G. Assessment of Indian Medical Graduate (IMG)'s knowledge about emergency contraception (EC) in a medical college of Himachal Pradesh. Indian J Comm Health. 2021;33(3):440-445. https://doi.org/10.47203/IJCH.2021.v33i03.006

Source of Funding: Nil Conflict of Interest: None declared

\section{Article Cycle}

\begin{tabular}{|c|}
\hline Received: 07/06/2021; Revision: 16/07/2021; Accepted: 05/09/2021; Published: 30/09/2021 \\
\hline This work is licensed under a Creative Commons Attribution 4.0 International License. \\
\hline
\end{tabular}

\section{Abstract}

Background: Undergraduate curriculum of the medicine is created to ensure achievement of goal of "health for all" in India. In addition, it aspires graduates to meet or exceed global benchmark in knowledge, attitude, skills and communication (1). Objectives: 1) To assess undergraduates' knowledge regarding the types and correct usage of available Emergency Contraceptives. 2) To utilize the data base for capacity building by focusing on the Core Competency of Emergency Contraceptives. Methods: This cross-sectional study was done among 442 undergraduates of all the Profs in our college in September 2017 after approval from Institutional Ethical Committee (17/66) and informed verbal consent from the participants. This pretested, pre-designed and self-administered 11-questionnaire proforma in English was used as a tool of investigation. Results: Maximum participation was from 3rd and 4th year. $7.2 \%$ had a very poor knowledge, attempted 3 or less questions correctly. Only $14.5 \%$ attempted 8 or more questions correctly. Conclusion: Young population of our country forms the broad base of the pyramid, they should be provided with correct knowledge about EC for improving their reproductive health. Since these graduates are going to serve the community, their knowledge and skill in this core competency is going to help the community.

\section{Keywords}

Curriculum; Emergency Contraception (EC); Health; Informed Consent; Knowledge; Over the Counter (OTC); Undergraduate.

\section{Introduction}

Emergency contraception is method women can use after intercourse to prevent pregnancy $(1,2)$.

India contributes $17.5 \%$ of world's population having only $2.4 \%$ of land (2011 census), having $17.3 \%$ of world's unprotected couples and $20 \%$ of eligible couples with unmet need (3) Reaching 48 million additional users is bench-mark of progress towards commitment to enable users to choose and plan healthy reproductive life (4). In Himachal as per the 4th National Family Health Survey (2015-2016) the overall unmet needs were $15.7 \%$, versus $7.2 \%$ (2005-06). Pattern is same for spacing methods (5).
Pills, introduced under Family Welfare Program in 2003, declared over the counter (OTC) in 005 ofor the adults over the age of 18 years and is now (2013) available without age restriction. EC is back-up method used by women within first few days (pills 3- IUCD 5 days) of unprotected intercourse, breakage/slippage of condom, sexual assault, with efficacy of 95-99\%respectively $(6,7,8)$. EC is intended for occasional use only, not regular contraception (9). Knowledge and practice on EC are important because of high rates of unwanted and teenage pregnancies (10). Introduction of EC can prevent unintended pregnancies (11). Worldwide, 20,00000 illegal 
abortions take place annually ,97\% being in developing countries (12).

\section{Aims \& Objectives}

1. To assess undergraduates' knowledge regarding availability and correct usage of various Emergency Contraceptives.

2. To utilize the data base for capacity building by focusing on the Core Competency of Emergency Contraceptives.

3. To introduce the concept of cross cutting for effective co-ordination between Obstetrics \& Gynecology and Community Medicine to give a common window of exposure to the medical undergraduates.

4. To enable students to impart correct knowledge of Emergency Contraceptives to the women to safeguard their reproductive Health.

\section{Material \& Methods}

This cross-sectional study was done among 442 undergraduate medical students of all the Profs in a private medical college of rural hills in October 2017 after approval from Institutional Ethical Committee (IEC/17/66). We took the verbal consent of the participants before enrolling them in study.

A pretested questionnaire in English was devised to collect data. Questionnaire had 11 items to know the knowledge and awareness of EC, based on literature review. There are very few studies about awareness in medical students \& none in Himachal Pradesh. Score of one was given for each correct answer and of 0 for incorrect and 'I don't know' type responses. Based on total score achieved, knowledge level was categorized into poor ( $\leq 4$ points), average (5-7), and good (8-11). (Table 1)

Inclusion criterion was solely on the voluntary participation basis and physical presence of students in the class on the day of filling the format. All the students, who did not give consent, were excluded from the study. To reduce bias format was distributed to all the students present in class 15 minutes before the end of lecture. Moreover, on one bench only one person was made to sit to avoid discussions. Mobile phones \& books were collected before distribution of the questionnaire. All the formats were anonymous without mentioning the name of the student to maintain the privacy and the filled formats were collected immediately after 15 minutes.

Statistical analysis: Data collected was entered and analyzed using Microsoft excel sheet. For descriptive statistics results were expressed in terms of percentages. Association between variables was calculated by using chisquare test and $p$-value $<0.05$ was considered significant.

\section{Results}

(Table 2) shows that Maximum participation was from 3rd and 4 the year ( 26.5 and $22.4 \%$ ) respectively.

(Table 3) states that $7.2 \%$ of participants had very poor knowledge and attempted three or less questions correctly. $14.5 \%$ had attempted 8 or more questions correctly. Others $(78.3 \%)$ are in between.

(Table 4) shows that half of sample size could not attempt correctly even 5 questions.

(Table 5 ) depicts range of mean marks of students varying between four-eight to seven-two (in 2nd year and final year). Overall mean is 5.7 and Standard Deviation is 1.8.

In (Table 6), we can see that $>60 \%$ failed to give the correct answers to question numbers three, six, seven, eight, nine and 11 . These questions are very basic and form the part of core competence objectives of EC use.

(Figure 1) shows the mean of the correct answers of all the participants which is 5.7 with a SD of 1.8. Maximum questions attempted correctly by the participants were five or six. Results of the study show that the students are far below the expected level regarding the knowledge and practice of EC.

\section{Discussion}

In 2000-year, old literature, we find evidence of various herbs, several folklore and ineffective unscientific methods for abortion. Even today due to lack of accessibility to health facilities, ignorance and sociocultural factors, the women are undergoing for termination of pregnancy from untrained persons and the quacks. In India, $25 \%$ of the pregnancies are unwanted. Eight percent of maternal deaths are due to abortion related complications. In India, the knowledge on EC is inadequate not only among the potential users and the community, but also among the service providers, who can play a key role in EC awareness. Most of the studies highlight incomplete knowledge about EC among healthcare providers (13).

There is also element of unmet needs for family planning methods including the spacing methods. In Himachal as per the 4th National Family Health Survey in 2015-2016 the overall unmet needs were $15.7 \%$, against $7.2 \%$ done in 2005-06. It has almost doubled. Similarly, the unmet needs for spacing methods also doubled (5). In such cases the knowledge of EC is a necessity to avoid the unwanted pregnancy.

As per the protocol EC is recommended within 72-120 hours of an unprotected intercourse. Current methods available for the purpose are IUCD (within five Days) \& Hormones (three days). In India, Levonorgestrel (I-pill) tablet is approved by Govt. of India for EC.

In the current study, we had 442 students from all Profs. Maximum students participated from third and fourth year with percentage of 26.5 and $22.4 \%$ respectively. Least participation was from final year, as many students got detained either due to short attendance or they could not get through their exams.

Score was good in $14.5 \%$ only \& poor in $7.2 \%$ of total students. Large percentage of (78.3\%) students had average knowledge score of four to seven. Only one-eight 
percent students have perfect score of $11.1 .1 \%$ of participants scored zero, meaning they have not heard of EC. Mean score obtained by final year students was maximum since they are to appear in final examination. Mean score of second year students was least. Overall mean is 5.7 with SD of 1.8. (Means dispersion is less). Half of sample size could not attempt correctly even five questions. Maximum students could correctly answer five to six questions only. Mean score of 7.2 out of 11 was for final year students who were to appear in the final examination. The score is less, since this is a core competency, where we need to score far better.

In NCERT and Himachal Board of school education in senior secondary classes, chapter of Reproductive health is there, where students are given orientation towards Contraception. In Punjab School Education Board, the orientation of I -pills is given in the senior secondary classes. Besides, the social media and Mass media also put advertisements about the I Pills as Emergency Contraceptives to make the masses aware about the same.

Undergraduate medical college students are oriented to the basic knowledge of Contraception and emergency contraceptives. In Medical Colleges we start teaching Emergency Contraceptives in third semester in clinics and in sixth semester during theory lectures in Obstetrics and Gynaecology. In Community Medicine also the Contraceptives including Emergency Contraception are taught in third and fifth semesters. In the field training during Community Medicine the students are sensitized about the various National Programs concerning the Reproductive Health. Currently the teaching of various departments is not convergent. Integration of the various specialties is aimed to facilitate the learning process by making the learning more effective and student friendly. The students are going to be the physicians of first contact. If the IMG are clear in the fundamentals of the Emergency Contraceptives, they can effectively deliver the services in the field situation.

The provider's knowledge was poor in 3.6\%, average in $61.4 \%$, and good in $35 \%$ in study done at Tabriz (14). Knowledge was good in $30 \%$ as said by Rahaman et al. in research done in 2010 in India (15). In a study done by Lakde et al. at Maharashtra in women seeking abortion services, good knowledge about EC was observed in 5.8\% only, as this study was done in non-health professionals (16). Knowledge was inadequate in adolescent study participants in 2016 (47\% in males and $49 \%$ in females) in Anand and Sukhlecha study at Jamnagar (17).

Millions of women who could benefit from EC have never heard of it (18). Almost all of the students had knowledge about existence of EC (98.9\%) in our study. Findings are similar to study done by P Radha Kumari et al ,98\% of final year students had heard of EC(19).More than seventy percent students didn't know that it can be taken multiple times in single cycle $\&$ similar no of students didn't know that it can be taken by women who is already taking regular OCP's. More than $80 \%$ students were lacking the knowledge of its availability to the girl without her parents' consent \& alternative method of EC in the form of $\mathrm{Cu}-\mathrm{T}$. In a study done by Keerti et al $51.43 \%$ of nursing students were aware about the alternative method of EC (20). Almost $60 \%$ or even more than that didn't know that EC is without any major side-effects and its availability as OTC. Similar observations were made by Keerti S Jogdand \& Pravin N Yerpude in a study done on Nursing students, but in study done by Vijender K Agrawal \& Pooja Agrawal, Knowledge about OTC availability was observed in $75.6 \%$ of study population which was quite high $(20,21)$.

If we focus on first- \& second-year students, taking them as the educated persons from the community they belong to, their knowledge about this subject is far less, so they must be provided with some training programs to educate them about the correct knowledge of EC. There were five students who did not answer any question correctly and two with only one question. There is lot of advertisements in the mass media and social media. Also, in Human Science subjects also the Human Reproductive System and Family Planning Methods have been taught in Schools.

\section{Conclusion}

Ultimately, they are going to serve the community after qualifying the examination. They will not be able to do justice as their role as first contact physicians to the society. This is going to be detrimental to the reproductive health of the nation. Females of the reproductive age group belong to the vulnerable section of the community. Hence the remedial measure of $\mathrm{MCl}$ for the approach of IMG in the present scenario.

Unmet needs may necessitate the use of EC, thereby avoiding unnecessary morbidity and mortality related to illegal abortion.

\section{Recommendation}

There needs to be cross cutting and the two departments need to sync the training together to refine the learning process with the ultimate objective of mentoring our graduates to IMG comparable to the other developed countries of the world. The vertical and horizontal integration will give the IMG the opportunity to understand the subject in a holistic manner.

\section{Limitation of the study}

Lack of $100 \%$ attendance. This study is not a multicentric study and only students of our college were enrolled in the study. Relevance of the study (What it adds to the current knowledge) empowers undergraduates to a level so that they can appropriately counsel and help towards improvement of the reproductive health of women.

\section{Authors Contribution}

MJ: conception and design, acquisition of data, or analysis and interpretation of data. Drafting the article or revising it critically for important intellectual content. Final 

approval of the version to be published. JGV: conception and design, acquisition of data, or analysis and interpretation of data. Drafting the article or revising it critically for important intellectual content. Final approval of the version to be published. JK: conception and design, acquisition of data, or analysis and interpretation of data. Drafting the article or revising it critically for important intellectual content. Final approval of the version to be published. SM: conception and design, acquisition of data, or analysis and interpretation of data. Drafting the article or revising it critically for important intellectual content. Final approval of the version to be published. GS: conception and design, acquisition of data, or analysis and interpretation of data. Drafting the article or revising it critically for important intellectual content. Final approval of the version to be published.

\section{Acknowledgement}

All the students who participated in study.

\section{References}

1. Supe A, Seshadri KG, Kumar RS, Chalam PV, Singh P, Singh T et al. Curriculum Implementation Support Program of the Competency Based Undergraduate Medical Education Curriculum 2019; Medical Council of India. chapter 1, Introduction, pp 5

2. Amalba A, Mogre V, Appiah MN, Mumuni WA. Awareness, use and associated factors of emergency contraceptive pills among women of reproductive age (15-49 years) in Tamale, Ghana. BMC Womens Health. 2014;14:114. Published 2014 Sep 22. doi:10.1186/14726874-14-114

3. Family Planning Division. India's vision FP 2020: Ministry of Health and Family Welfare, Govt of India; 2014, chapter 1, Introduction, pp21.

4. Family Planning Division. India's Vision FP 2020: Ministry of Health and Family Welfare; Govt of India; 2014, chapter 3.2, Analyzing Current Scenario, pp30.

5. Lips I. National Family Health Survey (NFHS-4), 2015-16. International Institute for Population Sciences (IIPS), Mumbai, India. 2017:791-846.

6. Family Planning Division. India's Vision FP 2020: Ministry of Health and Family Welfare; Government of India; 2014, chapter 5.3, Ensuring Service Availability, pp 64.

7. Trussell J, Rodríguez G, Ellertson C. Updated estimates of the effectiveness of the Yuzpe regimen of emergency contraception. Contraception. 1999;59(3):147-151. doi:10.1016/s00107824(99)00018-9
[Assessment of Indian...] | Jindal M et al World Health Organization (WHO). Fact sheet: Levonorgestrel for Emergency Contraception. Special programme of research development and research training in human production. Geneva: WHO, 2005.chapter 3.1.2, Research and Development, pp 31.

9. Relwani N, Saoji A, Kasturwar NB, Nayse J, Junaid M, Dhatrak P. Emergency contraception: Exploring the knowledge, attitude and practices of engineering college girls in Nagpur district of central India. Natl J Community Med. 2012;3:14-9. Doi:10.18203/23206012.ijrms20174576

10. Tamire W, Enqueselassie F. Knowledge, attitude, and practice on emergency contraceptives among female university students in Addis Ababa, Ethiopia. Ethiop J Health Dev. 2007;21:111-6.

11. Puri S, Bhatia V, Swami HM, Singh A, Sehgal A, Kaur A. Awareness of emergency contraception among female college students in Chandigarh, India. Indian J Med Sci. 2007;61:338-46.

12. Henshaw SK, Singh $S$, Haas T. The incidence of abortion worldwide. Int Fam Plann Persp. 1999;25: S30-8.

13. Consortium on National Consensus for EC. Report and Recommendations, Organized by WHO-CCR in Human Reproduction, AlIMS in Collaboration with WHO, Ministry of Health and Family Welfare. New Delhi: ICMR; 2001. pp. 115

14. Mohammad-Alizadeh-Charandabi S, Farshbaf-Khalili A, Moeinpoor R. Emergency contraception: Providers' knowledge and attitudes and their relationship with users' knowledge and attitudes at public health centers/posts of Tabriz. J Caring Sci. 2012;1:53-9.

15. Rahaman H, Renjhen P, Kumar A, Pattanshetty S, Sagir A, Dubey H. A study on emergency contraceptive Practice among nursing staff in Sikkim, India-a cross sectional study. Australas Med J. 2010; 3:667-71.

16. Lakde RN, Parande MA, Wakankar PS. Knowledge of emergency contraception among women seeking abortion services at tertiary care hospital in Western Maharashtra. Int J Med Sci Public Health. 2018; 7:507-13.

17. Anand NI, Sukhlecha A. Awareness and attitude toward the use of emergency contraceptives among male and female adolescents of Jamnagar. Int J Med Sci Public Health. 2016;5:1900-4.

18. T Dejene, Assefa T, Belachew Tefera. Knowledge, attitude and practice of emergency contraceptives among Adama University female students. Ethiop J Health Sci. 2010;20:195-202.

19. Lakshmi GV, Radha PK, Naidu SA. Knowledge, attitude \& practices of emergency contraception among female medical students of Andhra Medical College, Vishakhapatnam. Int J Res Health Sci. 2014;2:507-10.

20. Jogdand SK, Yerpude PN. A study of knowledge \& attitude of nursing students towards EC. Int J Med Res Health Sci. 2013;2:5014.

21. Agrawal VK, Agrawal P. Knowledge, awareness \& perception of female students of emergency contraceptive pills. J Behav Health. 2013;2:230-5.

\section{Tables}

\section{TABLE 1 STUDY QUESTIONNAIRE}

\begin{tabular}{|c|l|c|}
\hline $\begin{array}{c}\text { S. No } \\
\text { Q1. }\end{array}$ & $\begin{array}{l}\text { Have you heard of the emergency contraceptive pill? } \\
\text { also known as morning after pill. Yes/No }\end{array}$ & Correct answer \\
\hline Q2. & $\begin{array}{l}\text { How long after having intercourse can the emergency contraceptive pill be taken? } \\
\text { Up to } 12 \text { hours } / 24 \text { hrs/48 hrs/72 hrs/don't know }\end{array}$ & Up to 72 hrs \\
\hline Q3. & $\begin{array}{l}\text { How many times can the emergency contraceptive pill be used in a month? } \\
\text { Once/Twice/Any no/Don't Know }\end{array}$ & Any no of times \\
\hline Q4. & $\begin{array}{l}\text { Is the emergency contraceptive pill } 100 \% \text { effective in preventing pregnancy? } \\
\text { Yes/No/Don't know }\end{array}$ & No \\
\hline Q5. & $\begin{array}{l}\text { Does the emergency contraceptive pill also protect against sexually transmitted infections? } \\
\text { Yes/no/don't know }\end{array}$ & No \\
\hline Q6. & $\begin{array}{l}\text { From where c a } n \text { a } 16 \text {-year-old girl get the e m e r g e ncy contraceptive pill? } \\
\text { Doctor/ pharmacist /either of the two }\end{array}$ & Either \\
\hline
\end{tabular}


INDIAN JOURNAL OF COMMUNITY HEALTH / VOL 33 / ISSUE NO 03 / JUL-SEP 2021

[Assessment of Indian...] | Jindal M et al

Q7. Can a doctor give a girl who is 16 , the emergency contraceptive pill without telling her parents? Yes Yes/no/don't know

\begin{tabular}{l|l|l|} 
Q8. & Does emergency contraceptive pill have serious side effects? & No
\end{tabular} Yes /no/don't know

Q9. Can the emergency contraceptive pill be used if a woman is already taking the regular contraceptive Yes pill?

Yes / No/ Don't know

Q10. How many tablets of emergency contraceptive pills to be taken after a single act of unprotected Single intercourse? Single tablet / Two tablets/Multiple/Don't know

Q11. Can Cu-T be used as emergency contraception? Yes/No/Don't know.

TABLE 2 STUDENTS PARTICIPATION IN THE STUDY (YEAR WISE OF M.B.B.S COURSE)

\begin{tabular}{|c|c|c|c|}
\hline \multicolumn{2}{|c|}{ Batch } & Frequency & Percent of total sample size \\
\hline \multirow[t]{6}{*}{ Valid } & First Year & 95 & 21.5 \\
\hline & $2^{\text {nd }}$ Year & 69 & 15.6 \\
\hline & $3^{\text {rd }}$ Year & 117 & 26.5 \\
\hline & $4^{\text {th }}$ Year & 99 & 22.4 \\
\hline & Final Year & 62 & 14.0 \\
\hline & Total & 442 & 100.0 \\
\hline
\end{tabular}

Maximum students participated from 3rd and 4 the year with percentage of 26.5 and $22.4 \%$ respectively

\section{TABLE 3 KNOWLEDGE SCORE AND NO OF THE PARTICIPANT}

\begin{tabular}{|c|c|c|c|}
\hline $\begin{array}{c}\text { Range of } \\
\text { score }\end{array}$ & Grade & Frequency & Percent \\
\hline $\mathbf{0 - 3}$ & Poor & 32 & 7.2 \\
\hline $\mathbf{4 - 7}$ & Average & 346 & 78.3 \\
\hline $\mathbf{8 - 1 1}$ & Good & 64 & 14.5 \\
\hline Total & Total & 442 & 100.0 \\
\hline
\end{tabular}

$7.2 \%$ had a poor knowledge and attempted 3 or less questions correctly. 14.5\% had attempted 8 or more questions correctly. Others (78.3\%) are in between.

\section{TABLE 4 SHOWING THE SCORES OF NUMBERS OF PARTICIPANTS AND PERCENTAGE OF PARTICIPANTS} ATTEMPTED CORRECTLY

\begin{tabular}{|c|c|c|}
\hline Knowledge score & Number of participants in the score group & Percentage of participants in this group \\
\hline 0 & 5 & 1.1 \\
\hline 1 & 2 & 0.5 \\
\hline 2 & 4 & 0.9 \\
\hline 3 & 21 & 4.8 \\
\hline 4 & 63 & 14.3 \\
\hline 5 & 127 & 28.7 \\
\hline 6 & 98 & 22.2 \\
\hline 7 & 58 & 13.1 \\
\hline 8 & 31 & 7 \\
\hline 9 & 22 & 5 \\
\hline 10 & 3 & 0.7 \\
\hline 11 & 8 & 1.8 \\
\hline Total & 442 & 100 \\
\hline
\end{tabular}

Half of sample size could not attempt correctly even 5 questions. There are 5 students who could not answer any question correctly.

TABLE 5 SHOWING THE MEAN AND STANDARD DEVIATION OF MARKS OBTAINED BY DIFFERENT YEARS

\begin{tabular}{|c|c|c|c|}
\hline Batch & Sample size & Mean of marks obtained & Standard. Deviation \\
\hline First Year & 95 & 5.04 & 1.675 \\
\hline $\mathbf{2}^{\text {nd }}$ Year & 69 & 4.87 & 1.723 \\
\hline $\mathbf{3}^{\text {rd }}$ Year & 117 & 5.74 & 1.718 \\
\hline $\mathbf{4}^{\text {th }}$ Year & 99 & 5.89 & 1.177 \\
\hline Final Year & 62 & 7.23 & 2.099 \\
\hline Total & 442 & 5.70 & 1.813 \\
\hline
\end{tabular}

Range of mean marks is varying between 4.87 to 7.23 (4.87 in 2nd year and $7.23 \%$ in final year (exams going batch). Overall mean is 5.7 with SD of 1.8 (means dispersion is less). Minimum score is 0 in 1st, 2nd, 3rd and final years. It's a grey area. 


\begin{tabular}{|c|c|c|}
\hline Q No & Question & $\begin{array}{l}\% \text { participants failed } \\
\text { to attempt Correctly in descending order }\end{array}$ \\
\hline 7 & $\begin{array}{l}\text { Can a doctor prescribe ECP to a } 16 \text { years old girl } \\
\text { without her parent's consent }\end{array}$ & $86.4 \%$ \\
\hline 11 & Cu-T as a method of Contraception & $83.9 \%$ \\
\hline 3 & How many times it can be taken in cycle & $78.3 \%$ \\
\hline 9 & Can ECP be given to a woman already on OCP & $72.6 \%$ \\
\hline 8 & Does ECP has serious side effects & $65,4 \%$ \\
\hline 6 & From where 16 years old girl can get ECP & $60.6 \%$ \\
\hline 10 & $\begin{array}{l}\text { How many tablets of emergency contraceptive pills to be taken after a single } \\
\text { act of unprotected intercourse? } \\
\text { Single tablet / Two tablets/Multiple/Don't know }\end{array}$ & $32.6 \%$ \\
\hline 4 & $\begin{array}{l}\text { Is the emergency contraceptive pill } 100 \% \text { effective in preventing pregnancy? } \\
\text { Yes/No/Don't know }\end{array}$ & $25.3 \%$ \\
\hline 2 & $\begin{array}{l}\text { How long after having intercourse can the emergency contraceptive pill } \\
\text { (Morning after pill) be taken? } \\
\text { Up to } 12 \text { hours } / 24 \mathrm{hrs} / 48 \mathrm{hrs} / 72 \mathrm{hrs} / \text { don't know }\end{array}$ & $15.2 \%$ \\
\hline 5 & $\begin{array}{l}\text { Does the emergency contraceptive pill also protect against some sexually } \\
\text { transmitted infections? } \\
\text { Yes/no/don't know }\end{array}$ & $7 \%$ \\
\hline 1 & $\begin{array}{l}\text { Have you heard of the emergency contraceptive pill? } \\
\text { also known as morning after pill. Yes/No }\end{array}$ & $2.7 \%$ \\
\hline
\end{tabular}

High percentage of students (> 60\%) failed to give the correct answers to question no 3,6,7,8,9 \& and 11. These questions form the core competency of IMG regarding knowledge and use of EC.

\section{Figures}

\section{FIGURE 1 HISTOGRAM OF PARTICIPANTS}

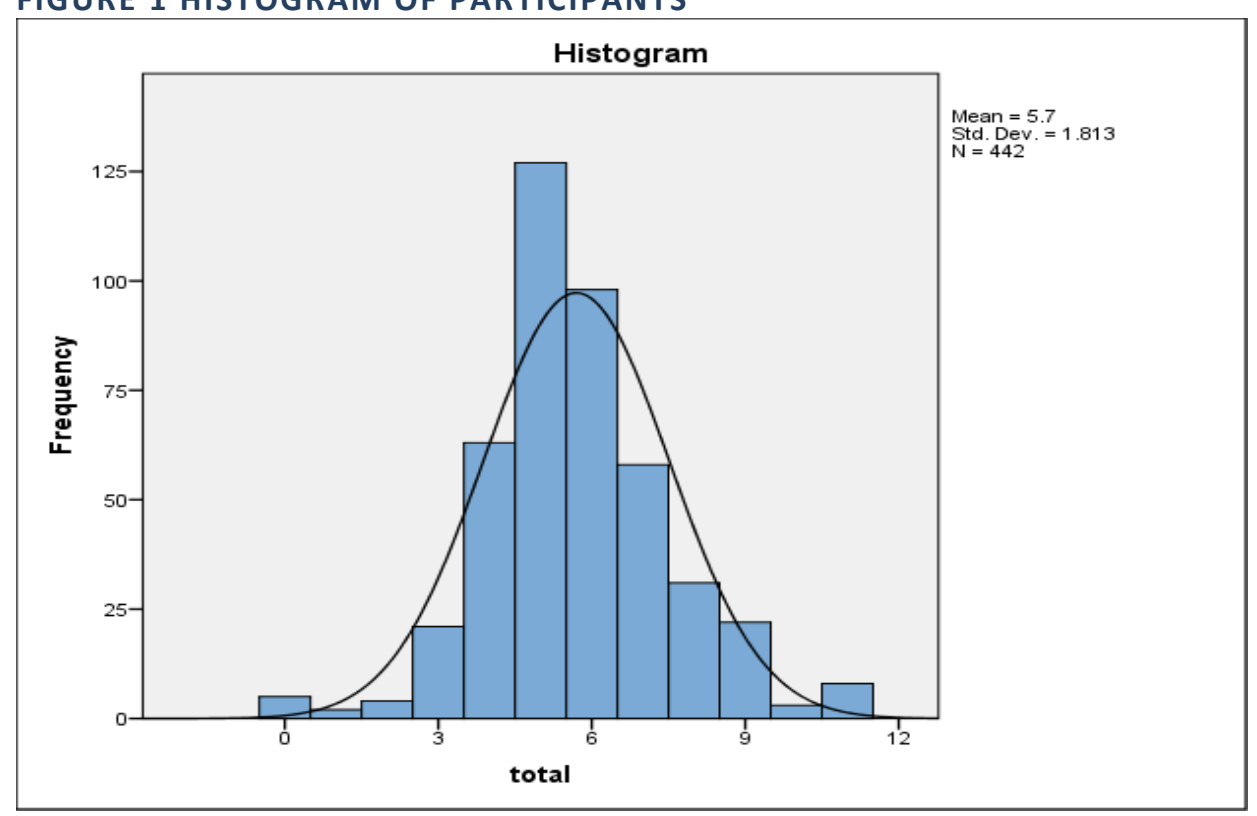

Mean is 5.7 and dispersion is less. Max students correctly answering 5-6 questions only 